\title{
1998 ile 2018 Yılları Arasında Yürürlükte Olan Yönetici Atama Yönetmeliklerindeki Okul Müdürü Değerlendirme Ölçütlerinin Karşılaştırılması
}

\section{Comparison of School Principal Assessment Criteria in the Executive Appointment Regulations Effective between 1998 with 2018}

\author{
Hüsnü Ergün ${ }^{a^{*}}$ \\ ${ }^{a}$ Dr. Milli Eğitim Bakanlığı, Denizli/Türkiye. \\ ORCID: 0000-0002-55018019
}

\section{MAKALE BİLGISI}

\section{Makale Geçmişi:}

Başvuru tarihi: 10 Ekim 2018

Düzeltme tarihi: 20 Kasım 2018

Kabul tarihi: 04 Aralık 2018

Anahtar Kelimeler:

Atama

Mevzuat

Okul müdürü

Seçme

\section{ARTICLE INFO}

\section{Article history:}

Received 10 October 2018

Received in revised form 20 November 2018

Accepted 04 December 2018

\section{Keywords:}

Appoint

Legislation

School principal

Selection

\section{ÖZ}

Bu çalışmanın amacı, 1998-2018 yılları arasında yürürlükte olan yönetici atama yönetmeliklerindeki okul müdürü değerlendirme ölçütlerini karşılaştırmaktır. Çalışma, doküman incelemesi türünde bir araştırmadır. Araştırmaya konu edilen dokümanlar, Türkiye'de 23.09.1998, 11.01.2004, 13.04.2007, 24.04.2008, 13.08.2009, 28.02.2013, 04.08.2013, 10.06.2014, 06.10.2015, 22.04.2017 ve 21.06.2018 tarihlerinde Resmi Gazete'de yayımlanan yönetmeliklerdir. Yönetici atama ya da görevlendirmeye ilişkin yönetmeliklere Resmi Gazete'nin internet sitesi üzerinden ulaşılmıştır. İlgili yönetmelikler resmi gazeteden alındığından orijinal olarak kabul edilmişlerdir. Yönetmelik metinleri okunmuş ve bu metinler hakkında yorumlar yapılmıştır. Yönetmelik ekinde yer alan yönetici değerlendirme formları eğitim durumu, yayım araştırma, eser, aldığı ödü1/cezalar, son üç yıllık sicil notu, yapılan hizmetler ve diğer hususlar açısından karşılaştırılarak yorumlanmıştır. Araştırma sonucunda yönetici değerlendirmede, lisans üstü eğitime verilen puan değerinin azaldığı, okul müdürlüğünden beklenen yeterliliklerin net olarak belirlenmediği söylenebilir.

\section{A B S T R A C T}

The purpose of this study is to compare the assessment criteria of the school principal that were effective in the executive assignment regulations between 1998\&2018. The study is a document review. The documents that are the subject of the research; Turkey on September 23 1998, November 11 2004, April 13 2007, April 24 2008, August 13 2009, February 28 2013, April 04 2013, June 10 2014, June 10 2015, April 222017 and June 212018 are dated regulations. The regulations related to the appointment of managers have been reached through the website of the Official Gazette. The relevant regulations were accepted as original because they were taken from the Official Gazette. The regulations were read and interpreted. Executive evaluation forms in the annex to the regulation were interpreted with regard to educational status, publication, research, awards, penalties, services, employment record and other issues. As a result of the research, it can be said that the value of the score given to master and doctoral education decreases in the evaluation of managers and the qualifications expected from the school directorate aren't clearly defined.

\section{Giriş}

Örgüt, üyeleri tarafindan kurulan bir koalisyon olarak tanımlanabilir (Bursalığlu, 2002: 15). Örgütün çalışanlardan bürokratik beklentileri olduğu gibi, çalışanın da örgütten bireysel beklentileri vardır. Askeri örgütlerde bürokratik beklentiler daha yoğun iken, eğitim örgütlerinde ise bürokratik beklentilerin askeri örgütler kadar yoğun olması beklenemez (Hoy ve Miskel, 2010: 27). Bu farkın nedenleri olarak, okullarda, emir komuta zincirinin askeri örgütler kadar yoğun olmaması, mesleki uzmanlaşmanın daha yoğun olması, yetki ve sorumluluk paylaşımının daha kolay olması, daha ademi merkezi bir yapı olması sayılabilir (Lunenburg ve Ornstein,2013:28).

* Sorumlu Yazar / Corresponding author

e-posta: husnuergun60@gmail.com 
Örgütlerin temel özellikleri; karmaşık, şaşırtıcı, aldatıcı ve anlaşılmalarının güç olması olarak sıralanabilir (Bolman ve Deal, 2013: 57). Bu durum yöneticilerin siyah kuğu'yu da olasılıkların içine almasını zorunlu hale getirmektedir. Siyah kuğu; sıra dıșı olması, olağanüstü etki gücüne sahip olması, beklenmedik olmasına rağmen ortaya çıkışından sonra açıklanabilir ve öngörülebilir bir takım açıklamalar bulmaya yöneltmesi nedeniyle yöneticiler tarafından hazırlıklı olunması gereken olgulardır (Taleb, 2007: 9). Günümüzde örgütlerin içerisinde bulunduğu durum yetersiz kaynaklar, artan rekabet gibi koşullar nedeniyle geçmişte olduğu kadar rahat ve olumlu değildir. Artık mevcut durumu korumak için bile keskin yönetimsel beceriler gerekmektedir (Cameron ve Quinn; 2017: 112).

Milli Eğitim Bakanlığı, okul çağına gelmiş tüm bireyleri örgün eğitimden geçirmeyi hedeflemektedir. $\mathrm{Bu}$ açıdan bakıldığında okullar, Milli Eğitim Bakanlığının genel amaçlarını gerçekleştirmesini sağlayan ana unsurlardan biri olarak karşımıza çıkmaktadır. Okuldaki insani ve maddi kaynakları bu amaçları gerçekleştirecek şekilde kullanacak kişi okul müdürüdür. Okul müdürlerinin seçimi okul niteliğinin arttırılmasında önemli bir yere sahiptir. Bu nedenle okul müdürü seçiminde yönetici değerlendirme ölçütleri önemli bir yer tutmaktadır. Okul yöneticisinin seçiminde titiz davranılmaması durumunda niteliksiz okul müdürleri atanabilir ve bu durum öğrencilerin yetiştirilmesinde nitelik sorununu karşımıza çıkartabilir. Okul müdürlerinin seçimi için yapılan öneriler arasında standardize edilmiş seçim süreci ve özel seçim kriterlerinin tanımlanması da yer almaktadır. Böylece her aday aynı seçim sürecinden geçirilirken, istenilen özelliklere sahip yöneticilerin seçimi de kolaylaşmaktadır (Blazer, 2009: 1). Ülkemizde bu hususlar yönetmeliklerde belirlenmektedir. Türkiye'de 23.09.1998, 11.01.2004, 13.04.2007, 24.04.2008, 13.08.2009, 28.02.2013, 04.08.2013, 10.06.2014, 06.10.2015, 22.04.2017 ve 21.06.2018 tarihlerinde resmi gazetede yayımlanan yönetmeliklerde değişik ölçütler ve yöntemler belirlenmiştir. Örneğin 13.04.2007 tarihli yönetmelikte amirlere \%100 takdir hakk1 verilirken diğer yönetmeliklerde farklı ölçütler değerlendirmeye alınmıştır.

Günümüzde okul müdürlüğü, belirsizliğin yoğun olduğu bir ortamda yapılmaktadır. Okulların demografik ve ekonomik özellikleri, merkezileşmesi, hesap verilebilirlikleri, okulun bulunduğu yerleșim yeri, büyüklüğü, kaynakları, öğrenci ve öğretmen oranı gibi değişkenler okul müdürünün rolünü ve işlevini etkilemektedir (Pashiardis ve Brauckmann, 2009: $120,121)$. Elbette değişen şartlarla beraber ölçütlerin değişmesi, öneminin azalıp artması mümkündür. Okul müdürü seçme ölçütleri belirlenirken okul müdürünün günümüzde hatta gelecekte oynayacağı rolün değerlendirilmesi gerekecektir. Bu ölçütler tüm okullarda geçerli olmayabilir. Aynı ölçütlerin kullanılmasının temel varsayımının her okulda aynı özelliklerde müdürün görev yapmasının mümkün olduğu düşüncesi olabilir. Yapılan bir çalışmada tüm okullara uyan bir okul müdürü profili olmadığı bulgusuna ulaşılmıştır (Baker, 2001: 124). Türkiye'de yapılan değerlendirme kriterleri arasında müdür adayının misyon ya da vizyon oluşturabilme, iletişim, teknolojik yeterlilik gibi ölçütler bulunmamaktadır. Her okulun gelecek resmi ile bu resme ulaşılmasını sağlayacak yolları farklılık gösterebilecektir. Bir köy okulunun bulunduğu yer ile olmak istediği yer arasında oluşan tablo ile merkezde yer alan bir okulun bulunduğu yer ile olmak istediği yer arasında oluşan tablo farklı olacaktır. Resim ne kadar güzel olursa olun, her iki okul için aynı resmi yapan bir okul müdürünün başarılı görülmesinin doğruluğu tartışılacaktır. Sürekli devamsızlık problemi olan bir okul ile başarı ve devam problemi olmayan bir okulda beklenen gelecek ya da atılacak ilk adımlar farklı olmalıdır.

Dünya değişmektedir. Okullardan beklentiler de yalnızca bugünü anlamayla sınırlı olmamalıdır. Dünyanın ihtiyaç duyduğu yeterlilikleri, bakanlık politikalarını anlayıp öğrencilerin bu doğrultuda yetiştirilmesine uygun ortamlar hazırlayacak okul müdürlerine ihtiyaç bulunmaktadır. Okul müdüründen vizyoner liderlik özellikleri göstermesi, okulun misyon ve vizyonunu gerçekleştirmek için iletişim becerisinin gelişmiş olması, teknolojinin gerisinde kalmaması, okulunun önünü açacak iyi bir mevzuat bilgisine sahip olması gibi özellikler aranabilir. Oyman ve Turan (2014) tarafından yapılan araştırmada, okul müdürlerinin iletişim, liderlik, mali konular, temel mevzuat ve yapısal süreçlerde eğitime ihtiyaç duydukları; etkili iletişim, eşitlik, dürüstlük, vizyon ve misyon, problem çözme becerilerinde yeterlilik kazandırılmaları gerektiğini ifade etmeleri araştırmacılar tarafından anlamlı görülmüştür (Oyman ve Turan, 2014: 24).

Başarılı bir okul liderinden beklentilerden biri de öğrenci başarısına odaklanan bir misyon ve vizyon geliştirmektir (Bottoms ve O’Neil, 2001: 8). Bunun gerçekleşmesi okul müdürünün okul hakkında bilgi sahibi olmasına bağıdır. Bunu, okulların planlı gelişim çalışmalarını daha sağlıklı bir şekilde yürütmelerini sağlayarak gerçekleştirebiliriz. Böylece, yeni gelen okul müdürü bir önceki okul müdürünün deneyimlerinden yararlanabilir, işlere sıfirdan başlamak zorunda kalmaz.

Günümüzde, okul müdüründen, okulun vizyonuna ulaşılmasına yardımcı olacak en iyi yaklaşım ve uygulamalar hakkında öğretmenlere, öğrencilere, velilere ve diğer paydaşlara rehberlik etmesi de beklenmektedir (Mathibe, 2007: 538). Okul müdüründen vizyona ulaştıracak stratejiler belirlemesi, bu stratejilerden paydaşları haberdar etmesi gereklidir. Bunun için okul müdürünün yönetim alanında eğitim görmüş olması ve iyi bir iletişim becerisine sahip olması beklenir.

Gülmez ve Yavuz, (2016: 229) tarafindan yapılan araştırmada; okul müdürlerinin eğitim yönetimi alanında eğitim almış olmaları, liderlik becerilerine sahip olmaları, müdür yardımcılığ becerilerinin olması, kendilerini sürekli geliştirmeleri ve günceli takip etmeleri gibi özelliklere sahip olmaları gerektiği ön plana çıkmıştır. Okul müdürlerinin yetiştirilmesinde, okulun amaçları, eğitim ve öğretim kaynakları, müfredat, finansal yap1, insan kaynakları ve değişim yönetimi gibi konular günümüzde önem kazanmaktadır (Oyman ve Turan, 2014: 3). Okul müdürlerinin yetiştirilmesinde önemli olan bu konular atamada da göz önünde bulundurulabilir. Tonga Krallı̆̆ı'nda okul müdürlerinin insan kaynakları, müfredat yönetimi, fiziksel kaynaklarının yönetimi ile liderlik ve girişimcilik konularında mesleki gelişim ihtiyaçlarının bulunduğu bulgularına ulaşılmıştır (Vete, 1990). Okul müdürleri zamanlarının çoğunu idari ve liderlik görevlerine, müfredat 
ve öğretimle ilgili görev ve toplantılara harcamaktadır (Schleicher, 2015: 18).

Okul müdürünün sistemde önemli bir yere sahip olması, seçiminde de belli kriterlerin olmasını gerekli kılmaktadır. Aksi takdirde kayırmacıllk dedikoduları örgütü sarabilecektir. Türkiye'de kayırmacılığın olduğuna ilişkin algılar bulunmaktadır (Aydogan, 2009; Özkanan ve Erdem, 2015; Kalman, Summak ve Cimen, 2017). Yapılan başka bir araştırmada elde edilen bulgular yönetici adaylarının sözlü sınavda başarılı olmalarının kişisel faktörlerden daha çok çevresel faktörlere bağlı olduğunu, sözlü sınavın yönetici yeterliklerini ölçmede son derece yetersiz kaldığını ortaya koymaktadır (Yolcu ve Bayram, 2015).

Konan, Çetin ve Yılmaz (2017) tarafından yapılan araştırmada, öğretmenlerin, 10.06.2014 tarihinde yayımlanan yönetmeliğin görevlendirmelerdeki tarafsızlık ve adalet endişelerini gidermediği, yönetici görevlendirmede daha adil, objektif, liyakat esaslarına dayalı bir değerlendirme yapılması gerekliliğini düşündükleri, müdür görevlendirmede kurum standartlarını yükseltecek kriterler belirlenmesi gerektiği bulgularına ulaşılmıştır. Güçlü vd., (2016) tarafından yapılan araştırmada, katılımcıların okul yöneticisi görevlendirme sürecinde yansızlığın sağlanabilmesi için informal güç odaklarının değerlendirme sürecini etkilememesi gerektiği görüşünde oldukları sonucuna ulaşılmıştır. Yönetici atamada temel sorun, belirlenen kategorilere verilen puanlardan ziyade ödüllerin bile kayırmacılık anlayışıyla verilebileceği gerçeğine ilişkindir. Temel sorun güven kültürünün oluşmaması ve eğitimin siyasallaştığına dair düşünce ve eylemlerin olmasıdır (Mazlum, 2018: 9).

18. Milli Eğitim Şurasında; "okul müdürlerinin seçimi ve istihdamında portfolyo, süreç değerlendirme vb. alternatif seçme yöntemleri esas alınarak geliştirilecek mesleki yeterlilikler dikkate alınmalı," tavsiyesinin hala yönetici atama ve görevlendirmelerde hayata geçirilmediği görülmektedir (MEB, 2010: 5). On Sekizinci Milli Eğitim Şurasında alınan bu karar okul müdürlerinin değerlendirilmesinin değişmesi gerektiğine ilişkin bir beklenti olarak değerlendirilebilir.

2004 yılından 2010 yılına kadar yönetici atama ve görevlendirme ile ilgili olarak yaklaşık 30 adet yönetmelik ve genelge çıkarılmıştır (Taş ve Önder, 2010: 176). Türkiye'de bu tarihten önce ve sonra (23.09.1998, 11.01.2004, 13.04.2007, 24.04.2008, 13.08.2009, 28.02.2013, 04.08.2013, 10.06.2014, 06.10.2015, 22.04.2017 ve 21.06.2018 tarihlerinde) Resmi Gazete'de yayımlanan yönetmeliklerin sayısının fazla olması da bu değerlendirme kriterlerinde tam olarak netliğe ulaşılamadığını göstermektedir.

Türkiye'de “meslekte esas olan öğretmenliktir" anlayışı benimsendiğinden okul yöneticilerinin öğretmenler arasından seçilmesi yoluna gidilmektedir (Balyer ve Gündüz, 2011: 192). "Meslekte aslolan öğretmenliktir." anlayışı kaliteli okul yöneticisi yetiştirmenin önünde engel olmayıp, asıl sorunun bu maddeyi referans gösterip değişimin öncülüğünün yapılmaması ve radikal kararların alınmamasıdır (Cemaloğlu, 2005: 266).

21.06.2018 tarihli Millî Eğitim Bakanlığ1 Eğitim Kurumlarına Yönetici Görevlendirme Yönetmeliğinin 14. maddesinde "yöneticiliğe ilk defa görevlendirme yazılı sınav ve sözlü sınav sonucuna göre; yöneticiliğe yeniden görevlendirme ise Ek-1'de yer alan Form üzerinden yapılacak değerlendirme sonucu belirlenen puanlar dikkate alınarak puan üstünlüğüne göre yapılır." ifadesi yer almaktadır. Adı geçen yönetmeliğin devamında yapılacak yazılı sınavda en az 60 alma zorunluluğu bulunmaktadır. Yazılı sınav konuları, okul yönetimi ve halkla ilişkiler, Türkçe ve dil bilgisi, genel kültür, resmi yazışma ve protokol kuralları, değerler eğitimi, eğitim ve öğretimde etik, yaşam becerileri ve sosyal etkinlik ile mevzuat konularından oluşmaktadır. Yazılı sınav sonrası boş bulunan okul müdürlüklerinin üç katı kadar aday yazılı sınav puanına göre sözlü sınava alınmaktadır. Sözlü sınavda yazılı sınav konuları (mevzuat ve genel kültür), bir konuyu kavrayıp özetleme, ifade yeteneği ve muhakeme gücü, temsil kabiliyeti, liyakati, tutum ve davranışlarının göreve uygunluğu, özgüveni, ikna kabiliyeti ve inandırıcılığı, bilimsel ve teknolojik gelişmelere açıklığı yönlerinden değerlendirilmektedir (MEB, 2018). Sözlü sinav konularından bir konuyu kavrayıp özetleme, ifade yeteneği ve muhakeme gücü sözlü sinav yöntemiyle ölçülebilir. Ancak bunun da ölçeğinin geçerlik ve güvenirlik özelliklerini taşıması gerekmektedir. Sözlü sınav konularındaki diğer hususların sözlü sınav yöntemiyle ölçülmesinin mümkün olmadığı düşünülmektedir. Temsil kabiliyeti, liyakati, tutum ve davranışlarının göreve uygunluğu, özgüveni, ikna kabiliyeti ve inandırıcılığg, bilimsel ve teknolojik gelişmelere açıklığg gibi kriterler daha uzun bir sürede objektif bir şekilde ölçülebilir. Bu durum, seçilenlerin rastgele seçildiği düşüncesini uyandıracak ve sınava girenlerde torpil bulma isteğini arttıracaktır. Aksi durumda müdürde aranan özelliklerin daha objektif bir şekilde tespit edilmesi halinde müdür olmak isteyen hangi yönünün geliştirmesi gerektiğini bilecek ve bu göreve hazırlanacaktır. Okul müdürü olarak kişiyi sadece bir sınav puanına göre görevlendirmektense belli yetiştirme hususlarına dikkat ederek yetiştirmek daha uygun olabilecektir.

Bu çalışmanın amacı, 1998-2018 yıllarında yürürlükte olan yönetici atama yönetmeliklerindeki okul müdürü değerlendirme ölçütlerini karşılaştırmaktır. Bu amaçla okul müdürü değerlendirme formundaki ölçütler, eğitim durumu, yayım araştırma, eser, aldığı ödül/cezalar, son üç yıllık sicil notu, yapılan hizmetler ve diğer hususlar açısından karşılaştırılmıştır. Taş ve Önder (2010) tarafindan yapılan çalışmada, 2004 ve sonrası yıllarda yürürlükte olan Eğitim Kurumları Yöneticilerinin Atama ve Yer Değiştirmelerine İlişkin Yönetmeliklerin yönetici atamada getirdiği ortak ve farklı kriterleri belirlemek amaçlanmıştır. Söz konusu araştırmada; yönetmeliklerin temel ilkelerinin karşılaştırması, yönetici olarak atanacaklara ilişkin genel ve özel şartlar incelenmiştir. $\mathrm{Bu}$ araştırmada ise, müdür değerlendirme formları incelenirken, değerlendirme formlarının ölçütlerindeki değişmeler analiz edilmiştir.

\section{Yöntem}

Bu bölümde araştırmada kullanılan model, üzerinde çalışılan yönetmelikler ve yönetici değerlendirme formları üzerinden toplanan verilerin analizine ilişkin bilgiler sunulmaktadır. 


\subsection{Araştırma Modeli}

Araştırma doküman incelemesi türünde bir araştırmadır. Doküman, araştırılmak istenen konu hakkında bilgi sağlayan her türlü yazılı materyaldir (Balc1, 2000: 205). Dokümanlar, araştırmaciların müdahalesi olmadan kaydedilmiş metinleri ve görüntüleri içerir. Belge analizinde hem basılı hem de elektronik materyaller kullanılır. Gündemler, katılımcılar ve toplantı tutanakları; kılavuzlar; kitap ve broşürler; günlükler ve dergiler; etkinlik programları, mektuplar ve not defteri; haritalar ve çizelgeler; gazeteler; basın bültenleri; program önerileri, başvuru formları ve özetler; radyo ve televizyon programı senaryoları; örgütsel veya kurumsal raporlar; anket verisi ve çeşitli kamu kayıtları doküman incelemesinde kullanılır (Bowen, 2009; 27). Doküman incelemesi; dokümana ulaşma, dokümanların orijinalliğinin kontrol edilmesi, dokümanların incelenmesi ve anlaşılması, dokümanlardaki verilerin analiz edilmesi, verilerin kullanılması aşamalarından oluşmaktadır (Şimşek, 2009: 43).

\section{2. Çalışmanın Kapsamı}

Araştırmaya konu edilen dokümanlar, Türkiye'de 23.09.1998, 11.01.2004, 13.04.2007, 24.04.2008, 13.08.2009, 28.02.2013, 04.08.2013, 10.06.2014, 06.10.2015, 22.04.2017 ve 21.06.2018 tarihlerinde Resmi Gazete'de yayımlanan yönetmeliklerin ekinde bulunan okul müdürü değerlendirme formlarıdır (Meb, 1998; Meb, 2004; Meb, 2007; Meb, 2008; Meb, 2009; Meb, 2013a; Meb, 2013b; Meb, 2014; Meb, 2015; Meb, 2017; Meb, 2018).

\subsection{Verilerin Toplanması ve Analizi}

Adı geçen yönetmeliklere Resmi Gazete'nin internet sitesi üzerinden ulaşılarak başlanmıştır. İlgili yönetmelikler resmi gazeteden alındığından orijinal olarak kabul edilmiştir. Araştırma ile Türkiye'de 1998-2018 yıllarında yürürlükte olan yönetici atamaya ilişkin dokümanlarda okul müdürü değerlendirme ölçütleri karşılaştırılmıştır. Bu amaçla okul müdürü değerlendirme formundaki eğitim durumu, yayım araştırma, eser, aldığı ödül/cezalar, son üç yıllık sicil notu, yapılan hizmetler ve diğer hususlar açısından karşılaştırılarak yorumlanmıştır. Öncelikle yönetmelikler analiz edilmiş ve değerlendirme ölçütleri karşılaştırılarak yorumlanmıştır.

\section{Bulgular ve Yorumlar}

$\mathrm{Bu}$ bölümde "yönetici atama ya da görevlendirme yönetmelikleri eklerinde yer alan müdür değerlendirme formlarının değerlendirilmesi” ile ilgili bulgular ve yorumlar yer almaktadır.

Tablo 1'de görüldüğü gibi okul müdürü adayının görmüş olduğu yükseköğretimin her y1lı için 23.09.1998 tarihli yönetmelikte 5 puan verilirken, 11.01.2004 tarihli yönetmelikte bu durum eğitim alanında görülen yükseköğretimin her yılı için 5 puan, diğer alanlar için ise 4 puan olarak düzenlenmiştir. 13.04.2007 tarihli yönetmelikte her hangi bir değerlendirme formu kullanılmamış olup tamamen amirlerin takdirine bırakılmıştır. Bu tarihten sonra yürürlüğe giren yönetmeliklerde bu ölçüt 1 puan ile değerlendirilmiştir.
Tablo 1. Okul Müdürü Değerlendirme Formundaki Eğitim Durumu ile İlgili Ölçütler

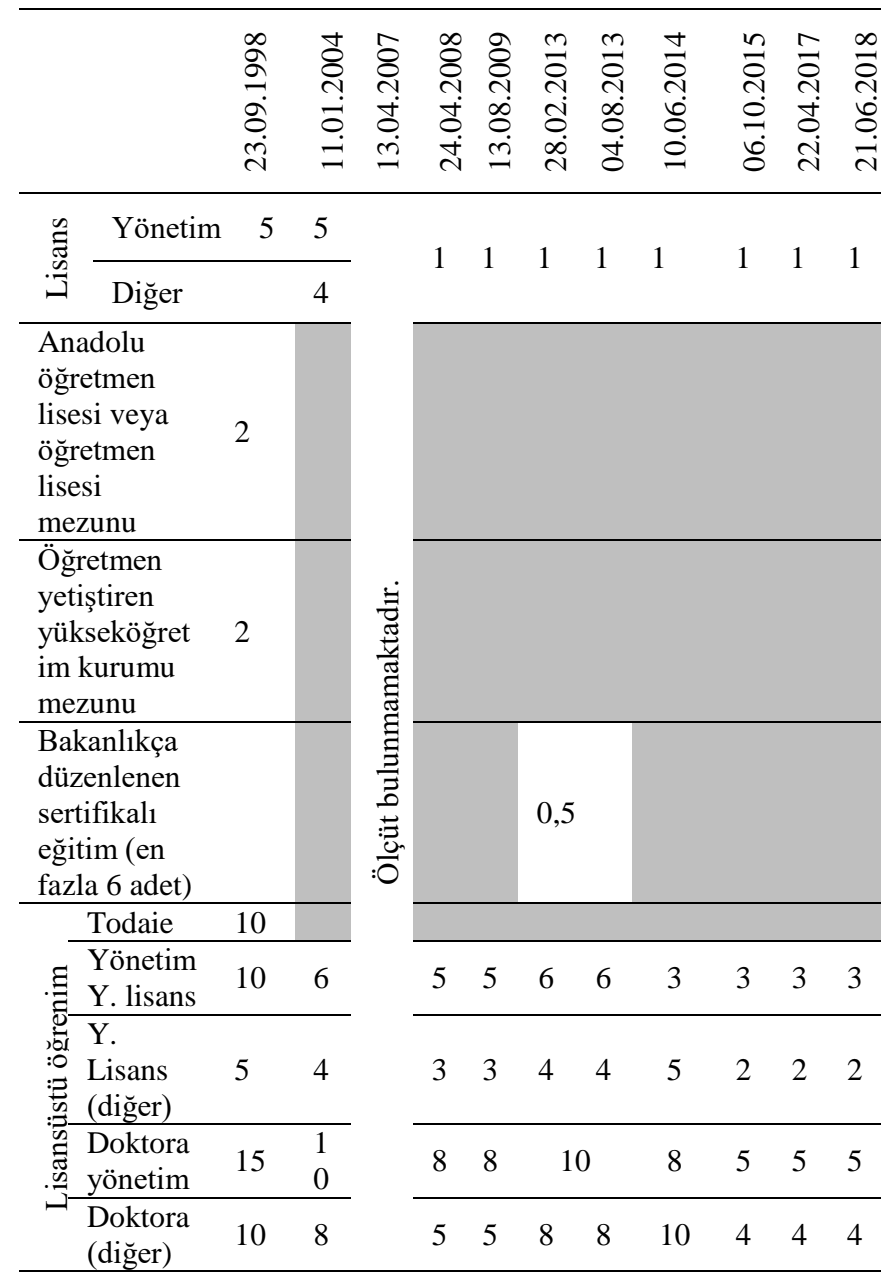

23.09.1998 tarihli yönetmelikte Anadolu öğretmen lisesi veya öğretmen lisesi ya da öğretmen yetiştiren yükseköğretim kurumu mezunu olan okul müdürü adayları bu iki hususta ikişer puan alırken, bu tarihten sonra çıkan yönetmeliklerde bu husus değerlendirmeye alınmamıştır. 23.09.1998 tarihli yönetmelikte TODAI'de lisansüstü öğrenim gören okul müdürü adayları bu hususta 10 puanla değerlendirilirken bu tarihten sonra yürürlüğe giren yönetmeliklerde bu husus değerlendirmeye alınmamıştır. Okul müdürü adaylarının lisansüstü öğrenimleri; lisansüstü öğrenim master (yönetim alanında), lisansüstü öğrenim master (diğer alanlarda), lisansüstü öğrenim doktora (yönetim alanında) ve lisansüstü öğrenim doktora (diğer alanlarda) ölçütleri ile değerlendirilmiş ve ölçütler her çıkan yönetmelikte daha az puanla değerlendirilmiştir. Örneğin yönetim alanında doktora yapan bir okul müdürü 1998 yılında 15 puan ile değerlendirilirken, aynı okul müdürü 2018 yılında 5 puan ile değerlendirilmektedir. Bakanlık tarafindan düzenlenen web tabanlı ve diğer sertifikalı eğitimlerin her biri (en fazla 6 adet) 28.02.2013 ve 04.08.2013 tarihli yönetmeliklerde 0,5 puan ile değerlendirilirken, bu tarihten önce ve sonra yürürlüğe giren yönetmeliklerde bu ölçüt değerlendirilmemiştir. Benzer durum illerde görev yapan ilköğretim/ Eğitim/ Maarif Müfettişlerinin göreve alınma süreçlerinde de görülmektedir. 1999 yönetmeliğinde ilköğretim müfettişliği için eğitim yönetimi lisans mezunu olma zorunluyken daha sonraki yıllarda bu alanda lisans/yüksek lisans/ doktora ile 
ilgili herhangi bir zorunluluk ya da ek bir puan verilmediği anlaşılmaktadır (Erkılıç ve Dilbaz, 2015: 13). Okul müdüründen beklentilerden biri, okuluna bir vizyon oluşturmasıdır. Bunun gerçekleşmesi, okul müdürünün ufkunun gelişmiş olmasına bağlıdır. Bu durumun ise, okul müdürünün aldığ 1 eğitimle gelişebileceği söylenebilir. $\mathrm{Bu}$ nedenle, okul müdürü adayının almış olduğu yönetim ile ilgili eğitimlerin puan değerinin artırılması daha doğru bir ölçüt olabilir.

Tablo 2. Okul Müdürü Değerlendirme Formundaki Yayım Araştırma ve Eser (Tez dahil) İle İlgili Ölçütler

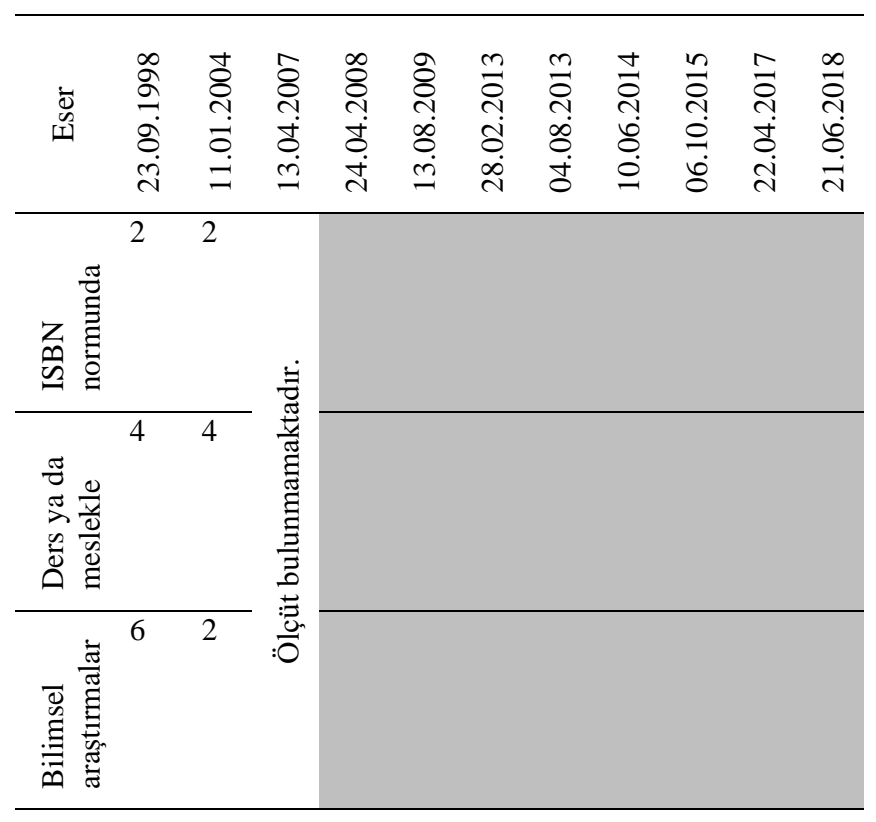

Tablo 2'de okul müdürü adayının yayım, araştırma ve eserlerine 23.09.1998 tarihli yönetmelikte ve 11.01.2004 tarihli yönetmelikte puan verilirken diğer yönetmeliklerde okul müdürü adayının bu çalışmalarına puan verilmediği görülmektedir. Okul müdürü adayının aldığı eğitime verilen değer düşerken, bu ölçüt de değerlendirmede dikkate alınmamıştır. Oysaki okul müdürünün düşüncelerini paylaşması bir anlamda okul müdürünün vizyonerliğinin, ikna edebilirliğinin anlaşılmasını sağlayabilecektir.

Tablo 3. Okul Müdürü Değerlendirme Formundaki Aldığı ödüller ile İlgili Ölçütler

\begin{tabular}{|c|c|c|c|c|c|c|c|c|c|c|}
\hline $\begin{array}{l}\frac{\bar{d}}{D} \\
\frac{\Delta 0}{D} \\
\infty\end{array}$ & 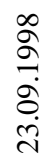 & 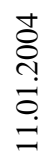 & 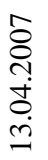 & 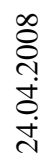 & 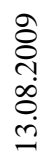 & 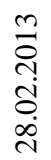 & 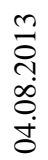 & 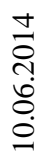 & $\begin{array}{l}\frac{n}{0} \\
\stackrel{n}{1} \\
0 \\
\dot{0}\end{array}$ & 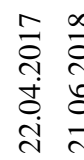 \\
\hline $\begin{array}{l}\text { Aylikla } \\
\text { ödül }\end{array}$ & 3 & 3 & \multirow{6}{*}{ 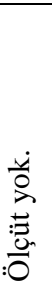 } & 8 & 5 & & 3 & 3 & 3 & 3 \\
\hline Takdir & 3 & 2 & & 5 & 3 & & 2 & 2 & 2 & 2 \\
\hline Teşekkür & & & & 3 & 1 & & 1 & 1 & 1 & 1 \\
\hline Başarı & & & & & & 1 & & & & \\
\hline $\begin{array}{l}\text { Üstün } \\
\text { Başar1 }\end{array}$ & & & & & & 4 & & & & \\
\hline Ödül & & & & & & & & 5 & 4 & 4 \\
\hline
\end{tabular}

Tablo 3'te görüldüğü gibi, okul müdürü adayının aldığ1 ödüller ile ilgili ölçütler 24.04.2008 ve 13.08.2009 tarihli yönetmeliklerde artış gösterirken sonraki yıllarda 1998 yılında yayınlanan yönetmelikteki haline döndüğü söylenebilir. 24.04.2008 tarihinde yayımlanan yönetmelik ile teşekkür belgesine de puan verilmeye başlanmıştır. 13.08.2009 tarihli yönetmelikte başarı ve üstün başarı belgesine puan verilirken, 10.06.2014 tarihinden itibaren ödüllere de puan verilmektedir. Millî Eğitim Bakanlığı Personeline Başarı, Üstün Başarı Belgesi Ve Ödül Verilmesine Dair Yönergede “ödül” Üstün Başarı Belgesi verilenlere en yüksek devlet memuru aylığının (ek gösterge dâhil) \%200'üne kadar yapılabilecek ödemeyi ifade etmektedir. 24.04.2008 tarihinden itibaren ödül alan personele müdürlük adaylığında pozitif ayrımcılık yapıldığı söylenebilir. Bu durum, çalıșkan personelin ödüllendirilmesi için olumlu iken, çalışmaları görülmeyen öğretmenlerin müdür olmalarında engel olarak karşımıza çıkabilmektedir.

Tablo 4. Okul Müdürü Değerlendirme Formundaki Son üç yıllık sicil notu ortalaması İle İlgili Ölçütler

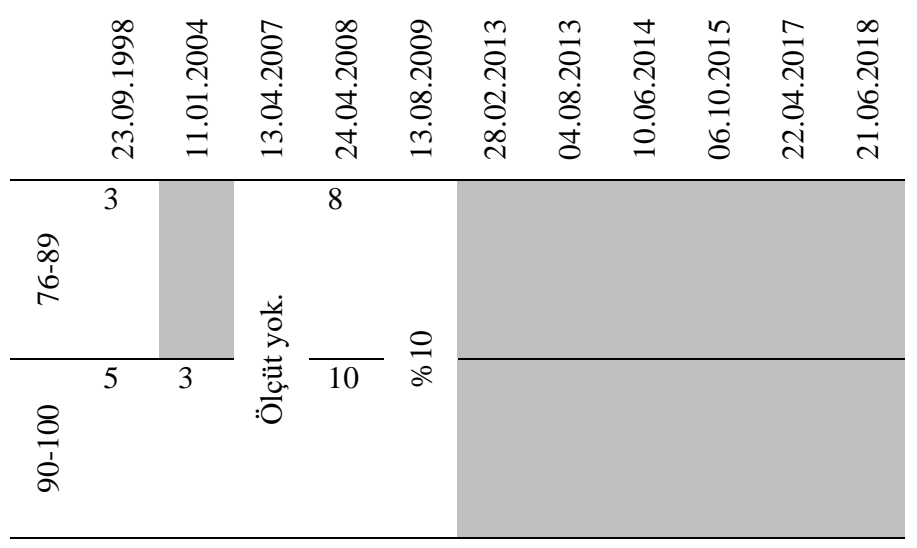

Tablo 4'de görüldüğü gibi, okul müdürü adayının son üç yıllık sicil notu ortalaması ile ilgili ölçütler 23.09.1998 tarihli yönetmelikte 76 ve üstü puanlar için değerlendirilirken 11.01.2004 tarihli yönetmelikte 90 ve üstü puanlar için değerlendirilmektedir. 28.02.2009 tarihli yönetmelikte ise üç yıllık sicil notu ortalamasının \%10'u alınmaktadır. 24.04.2008 ve 13.08.2009 tarihinde yayımlanan yönetmeliklerde sicile verilen değer artarken bu tarihten sonra yayımlanan yönetmeliklerde sicil yönetmeliğinin kalkmasının da etkisiyle değerlendirme dışı bırakılmıştır.

Tablo 5'te görüldüğü gibi, okul müdürü adayının aldığ1 cezalar ile ilgili ölçütler 23.09.1998 ve 11.01.2004 tarihli yönetmeliklerde dikkate alınmazken, 24.04.2008 ve sonrasında yayımlanan yönetmeliklerde okul müdürü adaylarının değerlendirilmesinde dikkate alınmaya başlanmıştır. Okul müdürünün okulda problem çözücü biri olması gerektiği, aksine problem kaynağ gerektiği düşünüldüğünde, disiplin cezalarının değerlendirilmesi gerektiği söylenebilir. Ancak, görevi dışında bir şeye karışmayan personel ceza almayabilirken, okulunun gelişimi için para toplamaya çalışan bir öğretmen ceza alabilmektedir. $\mathrm{Bu}$ durum okul için yapilan fedakârlıkları tartışmaya açabilmektedir. 
Tablo 5. Okul Müdürü Değerlendirme Formundaki Aldığı Cezalar İle İlgili Ölçütler

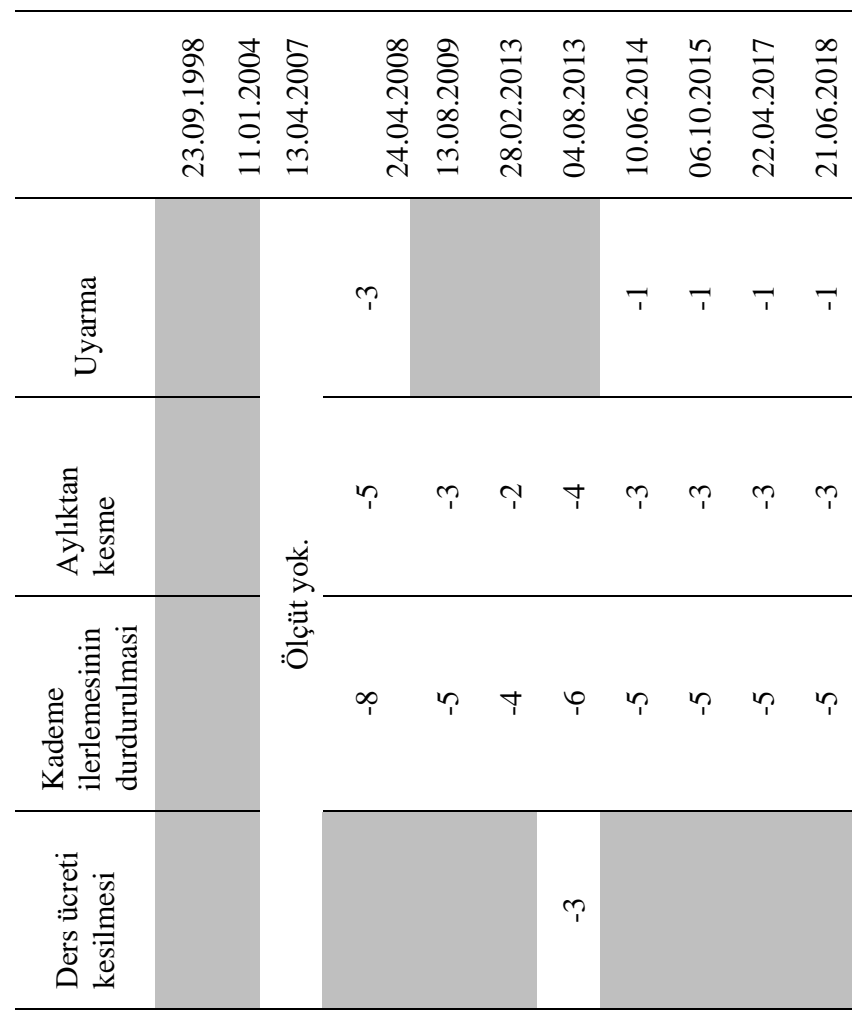

Tablo 6'da görüldüğü gibi, okul müdürü adayının “yapılan hizmetler" ölçütleri için yönetmeliklerde genel olarak katılmış olduğu hizmetiçi eğitim programı; yönetim alanında hizmetiçi eğitim, kurs, seminer; birinci kademe yöneticilikteki toplam hizmeti; ikinci kademe yöneticilikteki toplam hizmeti; üçüncü kademe yöneticilikteki toplam hizmeti; dördüncü kademe yöneticilikteki toplam hizmeti; lisans düzeyinde öğrenim görmüş atölye, laboratuvar ve meslek dersleri öğretmenlerinden, mesleki ve teknik ortaöğretim okul müdürlüklerine başvuranlar; öğretmenevi, lokal, eğitim merkezi ve sosyal tesislerde yöneticilik hizmeti, zorunlu hizmet bölge kapsamında geçen hizmetleri; yurtdışı görevlerindeki hizmeti; vekaleten müdür yardımcılığında geçen her yıl; asaleten müdür yardımcılığında geçen her yıl için; vekaleten müdür baş yardımcılığında geçen her yıl; asaleten müdür baş yardımcılığında geçen her yıl; vekaleten müdürlükte (A,B,C tipi) geçen her yıl; asaleten müdürlükte (A,B,C tipi) geçen her yıl; eğitim kurumu yöneticiliklerinde görevlendirme olarak geçen sürelerin her y1lı; ögrretmenlikte geçen süreler her y1l için (yöneticilikte geçen süreler hariç); müdür yetkililik veya müdür yardımcılığında geçen her bir yıl; kurucu müdür, müdür yardımcısı, müdür yetkililikte geçen her bir y1l; şube müdürü ve üstü kadrolarda geçen her yıl için değerlendirme yapıldığı anlaşılmaktadır.
Tablo 6. Okul Müdürü Değerlendirme Formundaki Yapılan Hizmetler ile İlgili Ölçütler

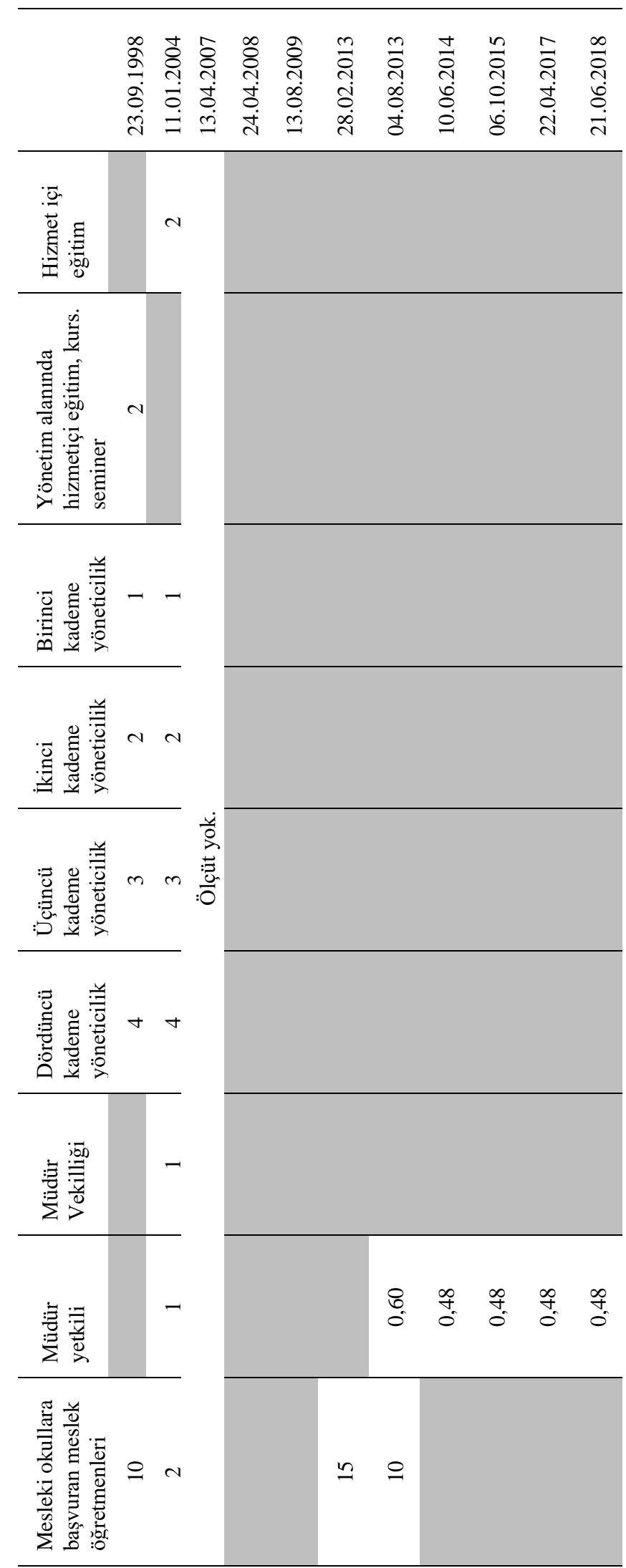


Tablo 6. Okul Müdürü Değerlendirme Formundaki Yapılan Hizmetler ile İlgili Ölçütler

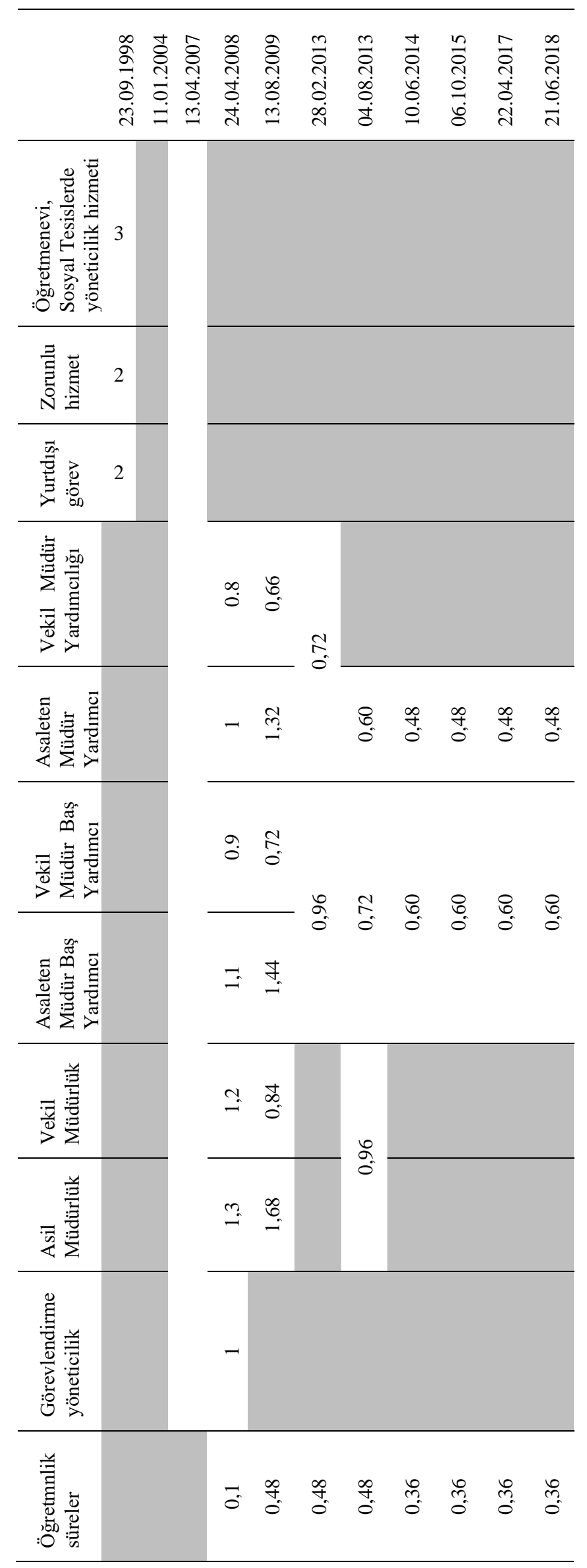

Tablo 6. Okul Müdürü Değerlendirme Formundaki Yapılan Hizmetler ile İlgili Ölçütler

\begin{tabular}{|c|c|c|c|c|c|c|c|c|c|c|c|}
\hline & $\begin{array}{l}\infty \\
\stackrel{2}{\sigma} \\
\ddot{g} \\
\ddot{\partial} \\
\dot{\lambda}\end{array}$ & 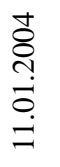 & 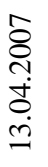 & 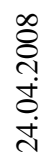 & $\begin{array}{l}\stackrel{8}{8} \\
\stackrel{\sim}{0} \\
\dot{0} \\
\stackrel{0}{0} \\
\dot{n}\end{array}$ & 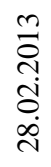 & 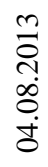 & 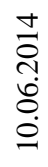 & 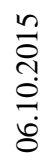 & 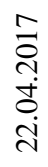 & 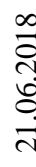 \\
\hline 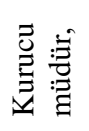 & & & & & & & & $\stackrel{\infty}{+\infty}$ & $\stackrel{\infty}{+\infty}$ & $\stackrel{\infty}{+}$ & $\stackrel{\infty}{+}$ \\
\hline 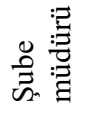 & & & & & & & & $\frac{2}{0}$ & $\frac{2}{0}$ & $\frac{N}{0}$ & $\stackrel{N}{a}$ \\
\hline
\end{tabular}

Tablo 6’da görüldüğü gibi, 23.09.1998 tarihli yönetmelikte okul müdür adayları "yönetim alanında hizmetiçi eğitim, kurs, seminer; birinci kademe yöneticilikteki toplam hizmeti; ikinci kademe yöneticilikteki toplam hizmeti; üçüncü kademe yöneticilikteki toplam hizmeti; dördüncü kademe yöneticilikteki toplam hizmeti; müdür vekilliğinde geçen süreler; müdür yetkili öğretmenlikte geçen süreler; lisans düzeyinde öğrenim görmüş atölye, laboratuvar ve meslek dersleri öğretmenlerinden, mesleki ve teknik ortaöğretim okul müdürlüklerine başvuranlar; öğretmenevi, lokal, eğitim merkezi ve sosyal tesislerde yöneticilik hizmeti, zorunlu hizmet bölge kapsamında geçen hizmetleri; yurtdışı görevlerindeki hizmeti değerlendirilmiştir. 11.01.2004 tarihli yönetmelikte alınan hizmetiçi eğitim genelleştirilmiş ve yönetim dişı hizmetiçi eğitimler de değerlendirmeye alınmıştır. Bu tarihten sonra yayımlanan hiçbir yönetici atama yönetmeliğinde hizmetiçi eğitim değerlendirmeye alınmamıştır. 11.01.2004 tarihli yönetmelikte müdür vekilliğinde ve müdür yetkili öğretmenlikte geçen sürelerde değerlendirmeye alınırken 24.04.2008 tarihli yönetmelikten itibaren vekâleten yöneticilikler müdür yardımcılığı, müdür başyardımcılığı ve okul müdürlüğü olarak ayrılmıştır. 1998 yılından itibaren kurucu müdürlük, vekâleten yöneticilik ve müdür yetkili öğretmenlik değerlendirmesine önem verilmiştir. Gerek tecrübe ve gerekse vefa açısından bakılacak olursa yapılan her türlü yöneticilik görevinin değerli sayıldığı söylenebilir. Üstelik bu durum, müdür adaylarının yöneticilik becerilerinin değerlendirilmesi için bir firsat olarak karşımıza çıkabilmektedir. Okul müdürlüğüne başvuracak bir öğretmenin müdür yardımcılığında geçen süreleri okul müdürünün yetiştirilmesi için bir fursat olarak görülebilir. Okul müdürü olmak isteyen bir öğretmen, müdür yardımcılığı, müdür baş yardımcılığı, okul müdürlüğü gibi okul yöneticiliği kariyer sıralamasını izlerse her bir basamak bir üst basamağın eğitim yeri olarak hayat bulabilir. Böylece, şube müdürlüğü ve üstü kadrolara yetiştirilecek insan kaynakları havuzu da oluşturulmuş olur. 
Tablo 7. Okul Müdürü Değerlendirme Formundaki Aldığı Diğer Hususlar ile İlgili Ölçütler

\section{市

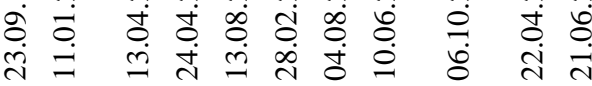

\section{$4 \quad 10$}

Takdir puanı

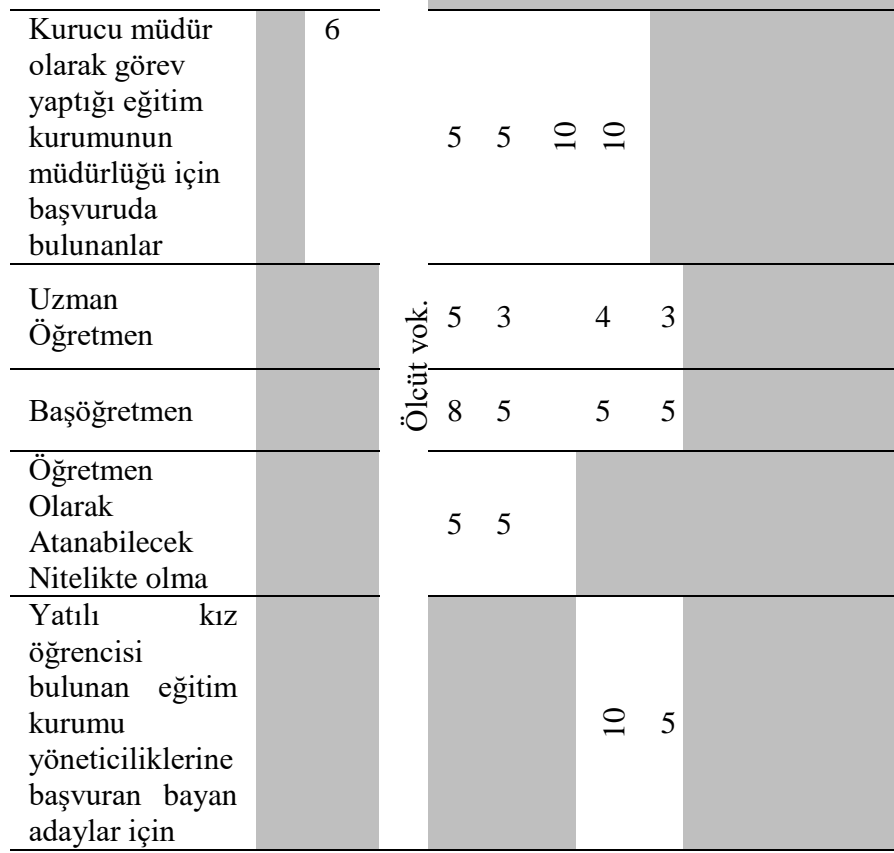

Tablo 7'de görüldüğü gibi, okul müdürü adayının “diğer hususlar ile ilgili” ölçütleri için yönetmeliklerde genel olarak takdir puanı; kurucu müdür olarak görev yaptığı eğitim kurumunun müdürlüğü için başvuruda bulunanlar; zorunlu bölge hizmeti kapsamında çalışılan süreler, uzman ve başöğretmenlik; atanmak istediği eğitim kurumunda öğretmen olarak atanabilme; yatılı kız öğrencisi bulunan eğitim kurumu yöneticiliklerine başvuran bayan öğretmenlere ek puan verildiği görülmektedir.

Tablo 7'de görüldüğü gibi takdir puanı 23.09.1998 ve 11.01.2004 tarihli yönetmeliklerde yer alırken, 13.04.2007 tarihli yönetmelikte ise takdir hakk1 \%100'e çıkmıştır. Ad1 geçen yönetmeliğin 12. Maddesinde gerekli şartları taşımaları kaydıyla atama yetkisi valiliklerde bulunanlar için ilçe millî eğitim müdürünün teklifi ve il millî eğitim müdürünün uygun görmesi üzerine vali tarafından atama yapılır. Eğitim kurumunun doğrudan il millî eğitim müdürlüğüne bağlı olması halinde il millî eğitim müdürünün teklifi üzerine vali tarafından atanır. Atama yetkisi Bakanlığa ait olanlar bakımından ise ilgili valiliğin teklifi üzerine Bakanlıkça atama yapılır." hükmü bulunmakta bunun dıșında değerlendirme kriterleri bulunmamaktadır. Farklı yönetmeliklerde sözlü sınav puanı verilerek de bir takdir hakkı oluşturulduğu görülmüştür.

Kurucu müdür olarak görev yaptığı eğitim kurumunun müdürlüğü için başvuruda bulunanlara puan verilmesi 11.01.2004 ve 04.08.2013 tarihleri arasında yayımlanan yönetmeliklerde yer alırken, zorunlu bölge hizmeti kapsamında çalışılan süreler 11.01.2004 tarihli yönetmelikte değerlendirilmiştir. Aslında bu iki husus öğretmenin fedakârca çalıșmasının göz önüne alınması şeklinde değerlendirildiğinde doğru bir hamle iken daha sonraki yıllarda bu ölçütten vaz geçilmiştir. Uzman ve başöğretmenlik için bir sınav yapıldığından ve bu sınava girmeyenler için haksız rekabet olușturduğundan, bu maddelerin kaldırılması örgütsel adalet için yararlı bir uygulama olmuştur. Atanmak istediği eğitim kurumunda öğretmen olarak atanabilme ölçütü 24.04.2008 ve 13.08.2009 tarihlerinde yayımlanan yönetmeliklerde değerlendirilirken, diğer yönetmeliklerde bu husus müdürlüğe başvuru için ön şart olarak karşımıza çıkabilmektedir. Çalıştığı kurumda öğretmenlik yapamayacak birinin, okulu ve öğretmenleri yönlendirmesi çok başarılı olamayabileceğinden bu uygulama da yöneticilik görevi için yararlı görülmüştür. Yatılı k1z öğrencisi bulunan eğitim kurumu yöneticiliklerine başvuran bayan öğretmenlere ek puan verilmesi 2013 yılında çıkarılan yönetmeliklerde uygulanırken bu bölümlerde sadece bayan öğretmenin atanması, öğrencileri yönlendirme ve etkileme açısından daha olumlu bir yaklaşım olmuştur.

\section{Sonuç, Tartıșma ve Öneriler}

Yaşamın sürekli değiştiği bir dünyada okul müdürünün seçimi ile ilgili ölçütlerin değişmemesi beklenemez. Ancak doğru ölçütlerle iyi bir müdür seçimi yapılabilir. Bu ölçütler tarafsızlığı sağlayacak ve müdür niteliğini arttıracak şekilde belirlenmelidir. Adı Milli Eğitim Bakanlığı olan bir bakanlığın her konuda olduğu gibi okul müdürü seçiminde de eğitime önem vermesi beklenmelidir. Ancak ülkemizde 1998 yılından itibaren çıkan okul yöneticilerinin atama ve görevlendirmesiyle ilgili yönetmeliklerde yönetim ile ilgili eğitime verilen değerin düştüğü görülmektedir. Bu durum, okulun niteliğinin olumsuz yönde etkilenmesinin, devlet okullarının özel okullar karşısında kan kaybetmesinin nedenlerinden biri olabilir. Devlet okullarının niteliğinin düştüğü algısı, velileri özel okullarda çare aramaya yöneltebilmektedir. Okul müdürlerine, yöneticilerin ihtiyaç duyacakları yeterlilikler eğitim yoluyla kazandırılabileceğinden, daha nitelikli okul müdürleri iyi bir eğitimle yetiştirilebilecektir. Nitelikli bir okul yöneticisi okulunun ufkunu açarak, okulun niteliğini arttırabilecektir. Lisansüstü eğitimin yöneticilerin mesleki gelişimlerine olumlu katkısı olduğu, okul müdürlüğünün meslekleşmesinde büyük öneme sahip olduğu ve eğitim yönetimi alanında uzmanlık ve doktora eğitimi alanların doğrudan atanmalarına yönelik bulgu ve önerilerin yer aldığı çalışmalar bulunmaktadır (Turhan ve Yaraş, 2013; Işık, 2003; Cemaloğlu, 2005). Bu nedenle okul müdürünün aldığ eğitime verilen önemin arttırılması gerektiği söylenebilir. Ayrıca okul müdürlerinin eğitimi sürekli hale getirilmelidir (Turhan ve Karabatak, 2015).

2004 yılından sonra yayımlanan okul yöneticilerinin atama ve görevlendirmesiyle ilgili yönetmeliklerde okul müdürü adayının yayım, araştırma ve eserlerine puan verilmemiştir. Oysaki okul müdürünün yaşantılarını kaleme alması, yenilikleri takip edip bunları okulunda uygulaması, sonuçları yayımlaması eğitim sisteminin gelişimine katkı sağlayabilir. Üstelik bu ölçüt okul müdürünün vizyonerliğinin anlaşılmasını sağlayabilir.

Okul müdürü adayının aldığı ödüller istisnasız tüm yönetmeliklerde puanla değerlendirilmektedir. İşler düzenli 
gittiğinde, yani duygular işe karışmadan rasyonel karar verildiğinde, ödül anlamlı olabilir. Ancak, yönetenin ve yönetilenin insan olduğu bir ortamda duyguların işe karışmaması neredeyse imkânsızdır. Ayrıca, çalışmaları görülmeyen öğretmenlerin müdür olmalarında ödül engel olarak karşılarına çıkabilmektedir. Türkiye'de kayırmacılığın, özellikle ödül konusunda kayırmacılığın, olduğuna dair algılar bulunmaktadır (Özkanan ve Erdem, 2015; Polat ve Kazak, 2014; Argon, 2016; Barut, 2015; Meriç ve Erdem, 2013). Bu nedenle, ödülden ziyade yöneticilerden istenen özellikler belirlenerek, bu özelliklerin yöneticilerde aranması daha doğru bir yaklaşım olabilecektir. Üstelik her ödül alan öğretmenin iyi bir okul müdürü olmasını beklemek de çok doğru bir yaklaşım olmayabilir.

Okul müdürü adayının son üç yıllık sicil notu ortalaması ile ilgili ölçütler 23.09.1998 tarihli yönetmelikte 76 ve üstü puanlar için değerlendirilirken, 11.01.2004 tarihli yönetmelikte 90 ve üstü puanlar için değerlendirilmektedir. 24.04.2008 ve 13.08.2009 tarihinde yayımlanan yönetmeliklerde sicile verilen değer artarken, bu tarihten sonra yayımlanan yönetmeliklerde sicil yönetmeliğinin kalkmasının da etkisiyle değerlendirme dışı bırakılmıştır. Sicil notu uygulaması olmaması nedeniyle bu ölçütün değerlendirme dışı bırakılmasının uygun olduğu söylenebilir. Sicil uygulamasının yerine performans değerlendirme uygulaması gelebilir. Ancak, sicil notunda ve günümüzde tartışılan performans denetim sisteminde okul yöneticilerinin tarafsızlık ve objektifliklerine ilişkin öğretmen kaygılarının bulunduğuna ilişkin araştırmalar bulunmaktadır (Akşit, 2006; Koçak ve Arslan, 2018; Kurban ve Tok, 2018). Böyle bir algının olduğu kriterinde okul müdürlüğünün değerlendirilmesinde kullanılması, müdürlük atamalarının objektif olmadığına ilişkin dedikodulara neden olabilecektir.

Okul müdürü adayının aldığı cezalar ile ilgili ölçütler 23.09.1998 ve 11.01.2004 tarihli yönetmeliklerde dikkate alınmazken, 24.04.2008 ve sonrasinda yayımlanan yönetmeliklerde okul müdürü adaylarının değerlendirilmesinde dikkate alınmaya başlamıştır. Okul müdürünün okulda problem çözücü biri olması gerektiği, aksine problem kaynağı olmaması gerektiği düşünüldüğünde disiplin cezalarının değerlendirilmesi gerektiği söylenebilir. Ancak, yönetici adayı sadece görevini yapıp fazla bir işe yanaşmıyorsa da disiplin cezası almayabilecektir. Oysa günümüzde çalışanlardan örgütlerine daha fazla katkı sunmaları beklenmektedir. Bu katkı zaman zaman yöneticilere yanlışlarını söyleme cesareti gerektirebilir. Yanlışlar karşısında susan, emirlere itaat eden, yaratıcılıklarını örgüt yararına sunmayan biri de ceza almayabilecektir. Zamanında dersine girip çıkan, kıyafet kurallarına uyan, hazırlaması gereken evrakları hazırlayan bir öğretmenin ya da yöneticinin ceza alması beklenmeyecektir. Ancak, bu durum onun yöneticilik özelliklerini taşıdığını şeklinde yorumlanmamalıdır. Ayrıca ceza, yönetici olması istenmeyen bir kişiye verilebileceğinden belirli suçları işleyenlere verilen disiplin cezaları yönetici değerlendirmede dikkate alınabilir. Örneğin okula bir defa geç kaldığı için uyarma cezası alan bir öğretmenin bu suçu müdürlük yapması yönünde engel değilken, sahte belge düzenleme, öğrenci dövme vb. suçları işleyenlerin okul müdürü olmasının engellenmesi gerektiği düşünülebilir.

Yönetici atama ya da görevlendirilme yönetmeliklerinde okul müdürü adayının yaptığı hizmetler değerli görülmeye başlanmış, özellikle asaleten yöneticilik/ vekaleten yöneticilik/kurucu müdür/müdür yetkili öğretmenlik tüm yöneticiler için 2008 yönetmeliğinden itibaren değerli görülmüştür. $\mathrm{Bu}$ durumda, gerek tecrübe ve gerekse vefa açısından bakacak olursak yapılan her türlü yöneticilik görevinin değerli sayıldığg söylenebilir. Örgütün, kendi yararına fazladan çalışan kişileri unutmaması, örgütün vefasını gösterebilecektir. Bu durum çalışanın moralini olumlu etkileyebilecektir. Üstelik bu uygulama müdür adaylarının yöneticilik becerilerinin değerlendirilmesi için bir firsat da olabilir.

Okul müdürü adayının diğer hususlar ile ilgili ölçütleri için yönetmeliklerde genel olarak takdir puanı, kurucu müdür olarak görev yaptığı eğitim kurumunun müdürlüğü için başvuruda bulunması; zorunlu bölge hizmeti kapsamında çalışılan süreler, uzman ve başöğretmenlik, atanmak istediği eğitim kurumunda öğretmen olarak çalışabilmesi yatılı kız öğrencisi bulunan eğitim kurumu yöneticiliklerine bayan öğretmenlerin başvuruda bulunması durumlarına ek puan verildiği görülmektedir. $\mathrm{Bu}$ madde de karşımıza sadece bayan olması, okulda girebileceği dersin bulunması, okulda kurucu müdürlük yapmas1, zorunlu bölge hizmetinde uzun yıllarca çalışmış olması özelliklerinin hiçbiri okul müdürünü iyi ya da kötü olarak tanımlamamıza yetmeyecektir. Bunun yerine okul müdürlüğünden beklentilerin neler olduğu, bu beklentileri karşılayacak okul müdüründe hangi özelliklerin bulunması gerektiğine ilişkin somut kriterlerin konulması daha uygun bir yaklaşım olabilecektir. (Cook, 1988; Gatewood, Feild ve Barrick, 2008; Ployhart, vd., 2006) (akt. Lin, 2013:25) müdür adayları ile yapılan görüşmelerin niteliğini arttırmak için iş tanımının anlaşılır olması, görüşme sürecinin standartlaştırılması, görüşmecilerin eğitilmesi ve üst yöneticilerin de görüşmede bulunmaları sağlanabilir. Türkiye'de de okul müdüründen beklentilerin net olarak ortaya konulması ve komisyonların mülakat eğitimi almış olanlardan oluşturulması gerektiği söylenebilir.

İmam-1 Gazali'ye göre yöneticilerin "adalet ve insafla" hareket etmeleri gerekmektedir. Adalet ve insafla hareket etmenin ölçütlerinden bazılarının ise adil olma, alimlerle çalışma, şefkatli olma, öfkesine sahip olma, ihtiyaç sahipleri ile ilgilenme, nefsine hakim olma olarak sayılmaktadır (İmam-1 Gazali, 2017). Şeyh Edebali, Osman Bey’e nasihatinde de benzer olarak, yöneticide uysallık, şefkatli olma, sabirlı olma, adaletli olma, motive etme gibi özelliklerden bahsetmektedir. Yüzyıllar önce yöneticide; sabır, şefkat, öfke kontrolü, alimlerle işbirliği, çalışanları motive etme gibi özelliklerin arandığı görülmektedir. Elbette günümüzde yöneticilerde sadece bu becerilerin olması yetmeyeceği gibi bu özelliklerin yöneticide olup olmaması gerekliliği de tartışılabilir. Burada ifade edilmek istenen, okul müdürlerinin sahip olması gereken yeterliliklerin net olarak belirlenmesidir. Böylece ölçme işlemi de kolaylaşacaktır. Günümüzde yöneticilerde aranan özellikler ölçme işlemine tam olarak yansıtılamadığından değerlendirmede de sıkıntı çekilmektedir. Öncelikle ölçülecek hususlar belirlenmeli, daha sonra bu ölçütlerin doğru ölçülüp ölçülmediği tartışılmalıdır. Yapılan 
çalışmalarda da okul müdürlüğü standartlarının tespit edilmesi gerektiği bulgusuna ulaşılmıştır (Aslan ve Karip, 2014; Turan ve Şişman, 2000). Ödül ve cezanın hak etmeyenlere verildiği gibi bir düşünce olması, alınan eğitimin değerinin düşürülmesi gibi hususlar, yönetici atamadaki dedikoduları arttırabilmektedir. Günümüzde yöneticilerden sabır, iletişim, vizyonerlik, adil olma, mevzuat bilgisi, teknolojik gelişmeleri takip edebilme gibi nitelikler aranabilmektedir. Balc1 (2001) okul müdürlerinden beklenen rolleri; stratejik planlama kapasitesine sahip olma, büyük resmi görebilme, okulu Pazar ilkeleri anlayışı ile yönetebilme, okulu geliştirebilme ve okulun hayat boyu eğitimin bir parçası olmasını sağlama olarak belirtmiştir. Bu hususlar ise kısa sürede ölçülemeyeceğinden, okul müdürleri daha geniş bir değerlendirme sürecine tabii tutulmalı, müdür yardımcılığı yetiştirme aşaması olarak kullanılabilmelidir. Tablo 6'da müdürlük değerlendirme formlarındaki kriterlerinden bazıları müdür yardımcılığı ya da müdür yetkili öğretmenlik gibi görevlerdir. $\mathrm{Bu}$ görevler oluşturulacak yönetim kariyer basamaklandırmalarına yerleştirilerek okul müdürlüğü yetiştirme alanı olarak değerlendirilebilir. Altın ve Vatanartıran (2014) tarafindan geliştirilen modelde okul müdürlüğü yetiştirilmesi modelinde okul müdürlerinin öğretmenlikten gelmesi, yüksek lisans ve hizmetiçi eğitimden geçmesi ve stajer müdürlük aşamalarını önermektedir. Bu araştırmanın önerisi ise yönetici kariyer sistemi oluşturularak okul müdürlüğün yönetici kariyer basamaklarından geçerek gelmesi olarak sunulabilir.

Sonuç olarak atanmak isteyen müdürlerin aldıkları eğitime önem verilmesi gerektiği ve müdür adayından beklenen niteliklerin günümüz yönetim anlayışına uygun olarak belirlenmesi gerektiği söylenebilir. Alınan eğitim okul müdürünün niteliğini arttırabilecektir. $\mathrm{Bu}$ nedenle, eğitim yönetimi alanında yüksek lisans ya da doktora yapmış olmanın önemi arttırılmalıdır. Yönetici kariyer sistemi getirilerek yapılan her bir yöneticilik görevinin bir üst yöneticilik için hazırlık ve eğitim süreci haline getirilmesi sağlanmalıdır. Öğretmenken çok başarılı olması ve ödül alması, bir kişinin iyi bir müdür olacağı anlamına gelmeyebilecektir. $\mathrm{Bu}$ nedenle iletişim, organizasyon, liderlik, problem çözme, vizyonerlik gibi okul müdürü ölçütleri ve bunların ölçekleri kullanılmalıdır. Değerlendirme, ölçütleri net olarak belirlenerek bir süreç dâhilinde müdürlük değerlendirme işlemi gerçekleştirilmelidir.

\section{Kaynakça}

Akşit, F. (2006). Performans değerlendirmeye ilişkin öğretmen görüşleri (Bigadiç ilköğretim öğretmenleri örneği). Sosyal Bilimler Araştırmaları Dergisi, 2, 76101.

Altın, F. ve Vatanartıran, S. (2014). Türkiye'de okul yöneticisi yetiştirme, atama ve sürekli geliştirme model önerisi. Ahi Evran Üniversitesi Kırşehir Eğitim Fakültesi Dergisi, 15(2), 17-35.

Argon, T. (2016). Öğretmen görüşlerine göre ilkokullarda yöneticilerin kayırmacılık davranışları. Kastamonu Eğitim Dergisi, 24(1), 233-250.
Aslan, H. ve Karip, E. (2014). Okul müdürlerinin liderlik standartlarının geliştirilmesi. Educational Administration: Theory and Practice, 20(3), 255-279.

Aydogan, İ. (2009). Favoritism in the Turkish educational system: nepotism, cronyism and patronage. Educational Policy Analysis and Strategic Research, 4(1), 19-35.

Baker, L. L. (2001). Principal selection and the stories superintendents tell. Electronic Teses and Dissertations. Paper 94, (Erişim: 18.09.2018), http://dc.etsu.edu/etd/94.

Balcı, A. (2000). Sosyal bilimlerde araştırma. Ankara: PegemA Yayıncılık.

Balc1, A. (2001). Etkili okul ve okul geliştirme. Ankara: PegemA Yayıncılık.

Balyer, A. ve Gündüz, Y. (2011). Değişik ülkelerde okul müdürlerinin yetiştirilmesi: Türk eğitim sistemi için bir model önerisi. Kuramsal Eğitimbilim, 4(2), 182-197.

Barut, B. (2015). İşyerinde irrasyonel davranışlar: "nepotizm, favorizm, kronizm" algısı üzerine nitel araştırma. Akademik Sosyal Araştırmalar Dergisi, 3(20), 382-394.

Blazer, C. (2009). How to select the best principals. Information Capsule Research Services, 818, 1-11.

Bolman, L. G. ve Deal, T. E. (2013). Organizasyonlar yeniden yapllandırmak. (A. Aypay ve A. Tanrı̈ğgen, Çev.). Ankara: Seçkin Yayıncılık.

Bottoms, G. ve O’Neil, K. (2001). Preparing a New Breed of School Principals: It's Time for Action. Southern Regional Education Board. (Erişim: 18.09.2018), https://www.wallacefoundation.org/knowledgecenter/Documents/Preparing-a-New-Breed-of-SchoolPrincipals.pdf.

Bowen, G.A. (2009). Document analysis as a qualitative research method.Qualitative Research Journal,9 (2), 27 40 .

Bursalığlu, Z. (2002). Okul yönetiminde yeni yapl ve davranış. Ankara: PegemA.

Cameron, K. S. ve Quinn, R. E. (2017). Örgüt kültürü örgütsel tanı ve değişim rekabetçi değerler modeli. ( $\mathrm{T}$. Kaya, Çev. ). Ankara: PegemA.

Cemaloğlu, N. (2005). Türkiye'de okul yöneticisi yetiştirme ve istihdamı: Varolan durum, gelecekteki olası gelişmeler ve sorunlar. Gazi Eğitim Fakültesi Dergisi, 25(2), 249-274.

Erkılıç, T. A. ve Dilbaz, E. (2015). Denetçi rol ve yeterlikleri bağlamında 1999, 2011 ve 2014 müfettişlik yönetmeliklerinin müfettiş yardımcısı atama ve yetiştirme anlayışlarının karşılaştırılması. Eğitimde Nitel Araştırmalar Dergisi, 3(2), 7-24.

Güçlü, N., Şahin, F., Tabak, B. Y. ve Sönmez, E. (2016). Türkiye'de okul yöneticisi görevlendirmeye ilişkin yönetici adayı görüşleri. GEFAD, 36(1), 51-71.

Gülmez, D. D. ve Yavuz, M. (2016). Okul müdürlerinin seçimi ve yetiştirilmesine yönelik bir model önerisi. PAÜ Ĕ̈itim Fakültesi Dergisi, 40, 220-233. 
Hoy, W. K. ve Miskel, C. G. (2010). Educational administration theory, research and practice. (S. Turan, çev.). Ankara: Nobel Yayın Dağıtım.

Işık, H. (2003). Okul müdürlerinin yetiştirilmelerinde yeni bir model önerisi. Hacettepe Üniversitesi Ĕ̈itim Fakültesi Dergisi, 24, 206-211.

İmam-1 Gazali (2017). İmam-ı Gazali'den yönetim sırları. İstanbul: Çelik Yayınevi.

Kalman, M., Summak, M. S. ve Çimen, I. (2017). Principal assignments in limbo: A qualitative study on the processesand potential outcomes of the recent principal assignment initiative in Turkey. Educational Process: International Journal, 6(1), 53-84.

Koçak, S. ve Arslan, S. Y. (2018). Ortaöğretim kurumlarında görev yapan öğretmenlerin performans değerlendirme uygulamalarına ilişkin görüş ve önerileri. Ahi Evran Üniversitesi Kırşehir Eğitim Fakültesi Dergisi, 19, 602620.

Konan, N., Çetin, R. B. ve Y1lmaz, S. (2017). Okul müdürü görevlendirmeye ilişkin öğretmen görüşleri. Ondokuz Mayıs Üniversitesi Eğitim Fakültesi Dergisi, 36(1), 147160.

Kurban, C. ve Tok, T. N. (2018). Okul müdürlerinin performans denetim sistemindeki rolünün, öğretmen görüşlerine göre değerlendirilmesi. Uşak Üniversitesi Sosyal Bilimler Dergisi, 11, 1-17.

Lin, Y.-H. (2013). Principal hiring practices: stories the principals tell. (Yayımlanmamış Doktora Tezi). USA, Iowa Üniversitesi.

Lunenburg F. C ve Ornstein A. C. (2013). Eğitim yönetimi. (G. Arastaman, Çev.). Ankara: Nobel Yayınevi.

Mathibe, I. (2007).The professional development of school principals. South African Journal of Education, 27(3), 523-540.

Mazlum, A. A. (2018). Milli ĕgitim sisteminde yönetici görevlendirme sorunsall: hukuksal açıdan değerlendirme. (Erişim: 29.08.2018). https://www.rese archgate.net/publication/324496549_Milli_Egitim_Siste minde_Yonetici_Gorevlendirme_Sorunsali_Hukuksal_ Acidan_Degerlendirme.

MEB (1998). Millî Ĕ̌gitim Bakanlı̆̆l eğitim kurumlarına yöneticilerinin atama ve yer değiştirmelerine ilişkin yönetmelik, (Erişim: 28.09.2018). http://www.resmi gazete.gov.tr/main.aspx?home=http://www.resmigazete. gov.tr/arsiv/23472.pdf\&main=http://www.resmigazete.g ov.tr/arsiv/23472.pdf.

MEB (2004). Millî Ĕ̌itim Bakanlı̆̆ ĕgitim kurumlarına yöneticilerinin atama ve yer değiştirmelerine ilişkin yönetmelik, (Erişim: 29.08.2018). http://www.resmi gazete.gov.tr/main.aspx?home=http://www.resmigazete. gov.tr/eskiler/2007/04/20070413.htm\&main=http://ww w.resmigazete.gov.tr/eskiler/2007/04/20070413.htm.

MEB (2007). Millî Ĕgitim Bakanlı̆̆l ĕgitim kurumlarına yöneticilerinin atama yönetmeliği, (Erişim: 29.08.2018). http://www.resmigazete.gov.tr/main.aspx?home=http:// www.resmigazete.gov.tr/eskiler/2004/01/20040111.htm \&main=http://www.resmigazete.gov.tr/eskiler/2004/01/ 20040111.htm.

MEB (2008). Millî Ĕ̆itim Bakanlığı ĕgitim kurumlarına yöneticileri yönetmeliği, (Erişim: 31.08.2018). http://www.resmigazete.gov.tr/main.aspx?home=http:// www.resmigazete.gov.tr/eskiler/2008/04/20080424.htm \&main=http://www.resmigazete.gov.tr/eskiler/2008/04/ 20080424.htm.

MEB (2009). Millî Eğitim Bakanlığı eğitim kurumlarına yöneticilerinin atama ve yer değiştirmelerine ilişkin yönetmelik, (Erişim: 03.09.2018). http://www.resmi gazete.gov.tr/main.aspx?home=http://www.resmigazete. gov.tr/eskiler/2009/08/20090813.htm\&main=http://ww w.resmigazete.gov.tr/eskiler/2009/08/20090813.htm.

MEB (2010). 18. Millî eğitim şûrası kararları öğretmenin yetiştirilmesi, istihdamı ve mesleki gelişimi. (Erişim: 22.09.2018), https://ttkb.meb. gov.tr/www/milli-egitimsuralari/dosya/12.

MEB (2013a). Millî Eğitim Bakanlı̆̆ ĕgitim kurumlarına yöneticilerinin atama ve yer değiştirme yönetmeliği, (Erişim: 05.09.2018), http://www.resmigazete.gov.tr/ main.aspx?home=http://www.resmigazete.gov.tr/eskiler /2013/02/20130228.htm\&main=http://www.resmigazete .gov.tr/eskiler/2013/02/20130228.htm.

MEB (2013b). Millî Ĕ̆itim Bakanlı̆̆l ĕ̆itim kurumlarl yöneticileri atama ve yer değiştirme yönetmeliği, (Erişim: 05.09.2018), http://www.resmigazete.gov.tr/ main.aspx?home $=$ http://www.resmigazete.gov.tr/eskiler /2013/08/20130804.htm\&main=http://www.resmigazete .gov.tr/eskiler/2013/08/20130804.htm.

MEB (2014). Millî Eğitim Bakanlı̆̆ına bă̆lı ĕ̆itim kurumlarl yöneticilerinin görevlendirmelerine ilişkin yönetmelik, (Erişim: 15.09.2018), http://www.resmi gazete.gov.tr/main.aspx?home=http://www.resmigazete. gov.tr/eskiler/2014/06/20140610.htm\&main=http://ww w.resmigazete.gov.tr/eskiler/2014/06/20140610.htm.

MEB (2015). Millî Ĕ̆itim Bakanliğl eğitim kurumları yöneticilerinin görevlendirilmelerine dair yönetmelik, (Erişim: 18.09.2018), http://www.resmigazete.gov.tr/ main.aspx?home=http://www.resmigazete.gov.tr/eskiler /2015/10/2011006.htm\&main=http://www.resmigazete. gov.tr/eskiler/2015/10/20151006.htm.

MEB (2017). Millî Eğitim Bakanlı̆̆ına bağlı eğitim kurumlarına yönetici görevlendirme yönetmeliği, (Erişim: 18.09.2018), http://www.resmigazete.gov.tr/ main.aspx?home=http://www.resmigazete.gov.tr/eskiler /2017/04/20170422.htm\&main=http://www.resmigazete .gov.tr/eskiler/2017/04/20170422.htm.

MEB (2018). Millî Eğitim Bakanlı̆̆l eğitim kurumlarına yönetici görevlendirme yönetmeliği. (Erişim: 27.09. 2018), http://www.resmigazete.gov.tr/eskiler/2018/06 /20 180621-8.htm.

Meriç, E. ve Erdem, M. (2013). İlköğretim okullarında görev yapan öğretmenlerin algılarına göre okul yönetiminde kayırmacılı. Kuram ve Uygulamada Eğitim Yönetimi, 19(3), 467-498. 
Oyman, N. ve Turan, S. (2014). Yeni atanan okul yöneticilerinin okul müdürlüğüne hazırlık ve yetiştirilme programlarına ilişkin düşünceleri. Turkish Journal of Educational Studies, 1(1), 1-31.

Özkanan, A. ve Erdem, R. (2015). Yönetimde kayırmacı uygulamalar üzerine nitel bir çalışma. MAKÜ İktisadi ve İdari Bilimler Fakültesi Dergisi, 2(4), 7-28.

Pashiardis, P. ve Brauckmann, S. (2009). Professional development needs of school principals, Commonwealth Education Partnerships, 10, 120-124.

Polat, S. ve Kazak, E. (2014). Okul yöneticilerinin kayırmacı tutum ve davranışları ile öğretmenlerin örgütsel adalet algıları arasındaki ilişki. Educational Administration: Theory and Practice, 20(1), 71-92.

Schleicher, A. (2015). Schools for 21st-century learners: Strong leaders, confident teachers, innovative approaches, international summit on the teaching professio., OECD Publishing, (Erişim: 18.09.2018), http://dx.doi.org/10.1787/9789264231191-en.

Şimşek, H. (2009). Eğitim tarihi araştırmalarında yöntem sorunu. Ankara Üniversitesi Eğitim Bilimleri Fakültesi, 42(1), 33-51.

Taleb, N. N. (2007). Siyah kuğu olasılıksız görünenin etkisi. (N. Arıbaş, Çev. ). İstanbul: Varlık Yayınları.

Taş, A. ve Önder, E.(2010). 2004 yılı ve sonrasında yayınlanan eğitim kurumları yöneticilerinin atama ve yer değiştirmelerine ilişkin yönetmeliklerin karşılaştırması.
Süleyman Demirel Üniversitesi Sosyal Bilimler Enstitüsü Dergisi, 2 (12), 171-185.

Turan, S. ve Şiman, M. (2000). Okul yöneticileri için standartlar: Eğitim yöneticilerinin bilgi temelleri üzerine düşünceler. Balıkesir Üniversitesi Sosyal Bilimler Enstitüsü Dergisi, 3(4). 68-87.

Turhan, M. ve Karabatak, S. (2015). Türkiye'de okul yöneticilerinin yetiştirilmesi ve yurtiçi alan yazında sunulan model önerilerinin incelenmesi. Turkish Journal of Educational Studies, 2(3), 79- 107.

Turhan, M. ve Yaraş, Z. (2013). Lisansüstü programların öğretmen, yönetici ve denetmenlerin mesleki gelişimine katkısı. Elektronik Sosyal Bilimler Dergisi, 12 (43), 200218.

Vete, V. (1990).Professional development and training needs of school principals in Tonga. (Erişim: 18.09.2018), http://ro.ecu.edu.au/theses/ 1116.

Yolcu, H. ve Bayram, A. (2015). Okul yöneticisi seçme sürecini deneyimleyen yönetici adaylarının sözlü sınav yöntemine ilişkin algıları. Eğitimde Nitel Araştırmalar Dergisi, 3(3), 102-126. 